\title{
Local Government: The Underutilized Governance Structure in Nigeria
}

\section{Acheoah Ofeh Augustine}

Department of Political Science, University of Lagos, Nigeria

"Corresponding author: Acheoah Ofeh Augustine, Department of Political Science, University of Lagos, Nigeria, Tel: 07032948290; E-mail:

acheoahaugustine6@gmail.com

Received date: September 11, 2018; Accepted date: October 18, 2018; Published date: October 24, 2018

Copyright: () 2018 Augustine AO. This is an open-access article distributed under the terms of the Creative Commons Attribution License, which permits unrestricted use, distribution, and reproduction in any medium, provided the original author and source are credited.

\begin{abstract}
This paper is a contributory input to the debate for a viable and effective Local Government system in Nigeria. The paper problematized the challenges facing local government administration in Nigeria on the weak institutionalization of Local government model as the third-tier of government by the 1999 Constitution. The major stumbling block to Local Government system in Nigeria is the institutionalization of a Joint State-Local governments Account under Section 162 sub-section (5, 6 and 7) of the 1999 constitution and the imposition of Local Council Chairmen/Councilors by state Executives which both contradict the ideals envisaged under section 7 Subsection (1) of the same constitution. The paper adopted the qualitative methods and anchored on the Legalistic theory of federalism postulated by Wheare. The paper interrogated some salient issues on why reform efforts had not bring about any meaningful structural change beyond mere paper work and constitutional rhetoric. This paper concluded and recommended that until fiscal autonomy and grass-root democracy are institutionalized at local levels of government in Nigeria, rural development will continue to be elusive and the Local Authorities will continue to operate as Local administration not Local Government for which autonomy is the hallmark.
\end{abstract}

Keywords: Institutionalization; Hallmark; Autonomy; Grass-root democracy; Local government; Administration

\section{Introduction}

Local government has been widely described as government closest to the people from the standpoint of administrative convenience, better grasp of the needs, peculiarities and aspirations of rural people. The philosophical rationale behind the local government model as a structure of governance is to address some of the most pressing needs of the rural people which are best taken care of within their local context, hence the appellation "Local government". This paper attempts an overview of the challenges facing local government administration in Nigeria; it paid special focus on the political, legal and administrative factors behind the crisis of governance and weak institutionalization the third-tier of government (Local Government) in Nigeria.

Ranny $[1,2]$ puts the following justifications forward for the emergence and incorporation of local government model into statecraft:

- It provides the rural people a platform for conducting their affairs in the context of their social, cultural and economic peculiarities;

- It provides a framework for grassroots mobilization and the sustenance of popular will and initiative for development;

- Local governments model functions as a two way channel of communication between the local populace, the central authority, thereby aggregating local interests and transmit to the center while at the same time keeping the local populace abreast with the activities, policies and programs of the central government;

- Local government serves as an edge against over-centralization of power at the Centre thereby providing administrative/governance structure for power devolution and de-concentration;
- Finally, Local government structures are veritable socio-political laboratories for testing the viability of policy and programs proposals of the government before incorporating them into the larger menu of governmental activities.

In spite of these viable attributes of local government models, they are yet to be fully utilized as governance structure in Nigeria in order to reap the intended benefit that gave rise to their adoption ass subunit of government driving rural development, hence the topic: "Local Government: the Underutilized governance structure in Nigeria".

Although, the 1999 Nigerian Constitution envisaged a democratically-structured local government system in Nigeria with financial and administrative autonomy as stipulated in Section7, subsection (1), however, the constitution dialectically contradicts this section in Section 162 Subsection (5-7) whereby the fiscal and financial autonomies were deliberately taken from them and made them subservient to the dictates of the State Governments where they exist. This section legalizes the manipulation of local government funds at will to the furtherance of elitist privileges of the state executives while starving the rural people both the governance needed at grassroots levels and as well as the funds needed for rural development.

Several reform efforts had been made by successive administration to restructure and reposition the local government as a viable governance structure at local levels. These efforts have not yielded any positive impact. This informed this write up, to assess the underlying political, administrative and legal impediments to effective local government system in Nigeria and make recommendations to address the challenges.

\section{Historical Background}

From the Nigerian experience, the Local government system predates other levels of government both regional government (from1946 to 1967) and the State level (from 1967 to date) and the 
Page 2 of 4

federal level (since 1954). Local government systems have always existed in pre-colonial Africa. These authorities performed the functions of communal order: security (through local vigilante), organizes markets and collect taxes, levies, create and maintain roads linking communities, outlaid village squares for festive events (the purpose of modern stadium). In pre-colonial Hausa-Fulani society, the emirs appoint "Hakkim" who was in charge of local district administration before Baba, a district of the Sokoto Caliphate fell to Colonial rule in1903. Modern local government system in postcolonial Nigeria are offshoots of the inchoate sole native authorities through which the British effected indirect rule in colonial Nigeria [3]. The colonial authority introduced multi-tier system of Local government: the County, Municipal, District and Divisional councils with different statuses and prerogatives. By this time they began to take their structural meanings.

Historical evidence had it that local government authorities in Nigeria were more autonomous than in post-colonial Nigeria. The local council in colonial era had wide range of prerogatives and functions over various matters such as: health, education, police, and judiciary(customary courts) among others.

In spite of being the first form of administrative structure in Nigeria, the Local government system is still evolving from post-colonial experience. Democracy itself originates and developed around the local government initiatives of the ancient Greek city state of Athens. In other climes, local government evolved side-by-side within the context of the cultural, historical and geopolitical delineations and the need to address the emerging peculiar needs of rural people.

There had been efforts at reforming the local government system in Nigeria without significant impact in their structure and functionality [4]. In 1976, the Federal Military Government of Nigeria introduced a unified local government system, making them a one-tier system, a significant departure from the multi-tier system that hitherto existed: Divisional, County, District, and Municipal Councils. Another landmark reform made them the third tier of government after federal and state as (LGAs).

The Buhari's administration instituted the Dasuki Local government Reform Panel which submitted its reports in 1984 with the following recommendations:

- That a place with a minimum population of 100.000 to 150.000 ;

- A place with a minimum tax paying population of 20.000;

- A place with a viable geographical contiguity;

- A place with economic and financial viability; as well as

- Administrative convenience.

The Dasuki report was incorporated and synthesized into the report of the Ibrahim Babangida administration's Political Bureau reports of 1992.

In spite of these reforms by past administrations, the incorporation of its provisions into the 1999 constitution, the provisions of the constitution that establishes and provide the statutory roles for local government in the Nigerian statecraft reflect one of the most contradictory wordings in constitutional framing in modern history. Section 162 sub-section (5, 6, and 7) contradicted Section 7 Subsection (1) which envisaged a democratically elected local government system with financial and administrative independence. Fifty eight years into independence Nigerian local government system is yet to be a viable governance structure thereby making grassroots development an elusive ideal to the rural people.

\section{Theoretical Framework}

This paper hinges on the legalistic theory of federalism advanced by Wheare [1] which underscores the centrality of legal rules defining inter-governmental relations in a federal state. Wheare [1] assertively remarked that: "by federal principle I mean the method of dividing power so that general and regional governments are each within a sphere co-ordinate and independent." The federal constitution defines the power relations between the central government and the subnational units. It devolves and de-concentrate powers in three legislative lists: the Exclusive list in which enumerated items of central jurisdictions are codified; the Concurrent list, in which all other matters not specifically assigned to the federal government are reserved for the respective states while the items of the Residual lists are left to Local government unit.

From Whear's postulations it could be understood that local government are sub-national units in a federal state system, an independent and co-jurally a sub-unit of government and not an appendage of other levels of government as it is currently being practiced in the Nigerian statecraft. In this light Local government are supposed to exist independently from other levels in a federal scheme with a democratically elected officials, chosen by the rural people to pilot their affairs, they are to operate with full fiscal and financial autonomies (with capacity to impose tax and levy in areas they operate, have an independent account for accessing funds from the national pool of revenues.

From the Nigerian experience, effort at reforming the structure of Local government system has not translated beyond paper work and constitutional rhetoric. The Local government system currently in place in Nigeria are not structured to serve the rural people but inverted and structured to remain subservient to the state government where they exist to the negation of their essence and federal principles.

A realist analysis of the State-local government relations will reveal that it has been one between the parasite-prey, they have served elitist privileges and the patronage system described in Richard Joseph's prebendalist analysis in which the state offices became "prebends' (i.e. converted to private properties handed out to clients in order to win and sustain power wealth and influence to the detriment of the yearnings and aspirations of rural people.

Acheoah [3] opines that so long as political powers rise and die at local government level (gubernatorial victory are determined by the number of local government won or lost in every state) the state Executives will continue to resist any positive effort at enthroning fiscal and political autonomies in the Nigerian federalism. This made them a critical socio-political laboratories for acquiring and sustaining power (a defeat of their ideological essence and intended purposes: to take governance close to the grassroots people.).

The fall out of this contraption is that to ensure their subservience, local government executives are single handedly handpicked and imposed on the rural people, democracy becomes a formality at the grassroots level. State executives thus dissolve local government executives and appoint caretaker committee at will. This explains why local government in Nigeria are not as close to the people (who did not have hands in chosen their executive), thus the question of accountability and transparency does not count at local levels vis-à-vis their stewardship to the rural people in so far as the local council executives are loyal tyo the state executives. 
Section 162 sub-section $(5,6,7$, and 8) of the 1999 constitution encroached on the spheres of the Local council but also institutionalized the predatory inter-governmental relations between the federal-state and local government. These ambiguities and contradictions negate the provisions envisaged for a viable, democratically elected and functional local government system in Nigeria under Section 7 sub-section (1) of the same constitution.

Instructively, Section 7 sub-sections 1 state: "the system of local government by democratically elected local government councils is under this constitution guaranteed; and accordingly, the Government of every state shall subject to section 8 of this constitution, ensure their existence under a Law which provides for the establishment, structure, composition, finance and functions of such councils".

These provisions were contradicted in Section 162 subsections $(5,6$, 7and 8) which state as follow:

- "the amount standing to the credit of the states in the Federation Account shall also be allocated to the States for the benefits of their local government councils on such terms and in such manner as may be prescribed by the National Assembly" (Sub-section 5) ;

- "Each state shall maintain a special account to be called "State Joint Local Government Account" into which shall be paid all allocations to the local government councils of the State from the Federations Account and from the Government of the State" (subsection6);

- "Each State shall pay to Local government Councils in its area of jurisdiction such proportion of its total revenue on such terms and in such manner as may be prescribed by the National assembly" (sub-section 7);

- "the amount standing to the credit of Local Government councils of a state shall be distributed among the local government councils of that State on such terms and in such manner as may be prescribed by the House of the State" (sub-section 8).

These provisions help one understand the legal impediments to rural development in Nigeria on one hand, and the larger constitutional inadequacies as part of the major stumbling block to the Nigerian federalism. An unpopular and an elitist constitution enacted into being by a military fiat through Decree 25 of 1999 by the outgoing military administration of General Abdulsalami Abubarkar, the Constitution has been one of the biggest obstacle to a viable and functional federal system in 21st Century Nigeria [3].

The Richard Joseph's Prebendalist perspective of the leadership crisis and miss-governance is instructive in this regard, to understand how the politics of patron-client relation has eaten the both the institutional edifices in public life as well as the place of ethics and accountability in the conduct of public assignments. According to Richard Joseph, public offices are converted first to private estates "prebends" which are now handed to clients in order to sustain the patronage system in which merit has been sacrificed. These drift in public life has chattered aspiration for grassroots development in Nigeria. The question that comes to mind is: why is the constitution deliberately ambiguous on the issue of Local government autonomy?

\section{The Legal, Political and Administrative Impediments to a Viable Local Government System in Nigeria}

The problematique of local government system in Nigeria is the exploitation and predatory inter-governmental relations among the tiers of government in federal Nigeria, particularly, institutionalization of state domination of local levels of government by Section 162 of the 1999 Constitution [4].

Both the statutory provisions for their establishment and their functioning were tailored to make them subservient to state authorities (a reflection of the bereave of federal idea by the framers of the 1999 constitution who left legal structure for a nominal federalism).

Understanding how local government authorities became preys to other federating units, Richard Joseph's "Democracy and Prebendalism Politics in Nigeria: the Rise and Fall of the Second Republic is quite revealing. It laid bare how the leadership crisis and mis-governance in post-colonial Nigeria is brought about by a corrupt system whereby public offices are converted to private estates, he called this "prebends" handed out for patronage to clients for their loyalties to the crop of unproductive and rent-seeking ruling elites. This patron-client relations thus determines who comes into the system (the recruitment process). In no tier of government is this drift in public life more visible than local government levels. This also brought to bear the centrality of local government to the acquisition and sustenance of power at state levels, in that victory at gubernatorial poll is predicated upon the number of local government won or lost within the state (gubernatorial power thus rise and die at local government levels).

Acheoah [3] argues that there exist a foundational flaw from the legal standpoint drawing from the 1999 Constitution of the federal Republic of Nigeria by deliberately blurring the lines that would have guaranteed fiscal autonomy and internal/grassroots democracy for Local Government Authorities which are critical to their viability and functionality.

Professor Wheare [1], in his "Federal Government" opined that the federating units are independent, co-coordinating co-jurally, and not subordinate or appendages as obtained in federal Nigeria.

To sustain their dominance on local governments in Nigeria, the federal and state governments have designated a plethora of offices, agencies, ministries and supervisory committees to ensure their subservience. Examples abound:

- Ministry of Local Government Affairs;

- Ministry (Commissioner) for Local Government and Chieftaincy Affairs;

- Local Government Caretaker Committees and the appointment of Sole administrator ship in their stead (after the dissolving Local Government Executives);

- The Office of the Special Adviser to the Governor on Local Government matters;

- The Houses and Senate Committees on Local Government Matters (at the national parliament);

- State Houses Committees on Local Government Matters.

- All these institutional paraphernalia are designed to keep local government within the grip and to effect the control of other federating units on Local government to the detriment of rural development [4].

The 10 per cent Internally Generated Revenues (IGRs) which are statutorily entitled to Local government are rarely disbursed to them. Amani (2012); Akindele and Oaopa (2002), regretted the practice whereby State Government traps the Federal allocations meant for Local government authorities within their states.

Acheoah [3] noted that this parasitic, predatory inter-governmental relation negates every ideal envisaged in federalism and represents one 
Page 4 of 4

of the failures and improper incorporation of federal idea as a way of organizing a political society [5].

In 2013 and 2017, there were efforts to reform local government system and reposition them for effective governance at grassroots level, however, the political values and priorities of the political elites at state levels will make it politically infeasible to secure the necessary majority required to have the federal Bill that seeks to restore local government autonomy in Nigeria. Because of their un-civic political culture an elitist privileges, they will continue to resist any autonomy for a sphere they see as their power life line (Local Government Councils) where their political power rises and dies.

With on apologist intent for military in politics, it must be stated that the reform effort made so far on Local Governments were carried out by successive military administration (even though military rule is an anathema to local government and antithetical to federalism: how?, there Central Command Paradigm which negates delegation of power or the existence of oversight/deliberative authorities that shares powers to ensures checks and balances).

The 1976, 1984 1nd 1992 reforms gave them their contemporary legal statuses in Federal Nigeria. The civilians are yet to improve on any gains made by the military regime on local government system in Nigeria; rather they pay lip service and oppose their autonomies thereby impeding the development of their people. Had the 774 local Government Authorities been developed, the entire Nigeria may have achieved the goal of equitable national

Development in that the 774 Local Governments in Nigeria made up both the 36 States and the Federal Republic of Nigeria. The failure to realize this fact is one of the missing point of national development planning in post-colonial Nigeria [3].

\section{Reform Efforts at transforming the Nigerian Local Government System: a Synoptic Overview}

The first major reform initiative on Local government in Nigeria was in 1976, when the Federal Military Government made them a onetier system in a clean break from the multi-tier system instituted by colonial authority: Municipal, County, District, and Divisional Councils with divergent structures, functions and prerogatives.

The Buhari-Idiagbon administration instituted the Dasuki Panel which came up with its report in 1984. Among other things, the Dasuki report recommended the following as fundamental to the creation of Local government Authority:
- That a place with a minimum population of 100.000 to 150.000 ;

- A place with a minimum tax paying population of 20.000

- A place with a viable geographical contiguity;

- A place with economic and financial viability; as well as

- Administrative convenience.

\section{Conclusion}

Babangida's administration instituted the Political Bureau, the reports of the political Bureau synthesized the Dasuki reports of 1984 and made the following recommendations:

- It for the first time provided for financial aotoomies for Local government by allowing them direct access to national revenues;

- It recommended for the abrogation of the Ministry of local government Affairs;

- It brought a landmark structural change by introducing legislative and executive arms to local government system in Nigeria;

- The Ibrahim Babangida's administration provided for 15 to 20 per cent statutory allocations to Local Governments authorities with effect from 1992 .

Many of these reforms were incorporated into the 1999 Constitution of the Federal republic of Nigeria. However, there are grey areas in the statute book which had impeded the ability of local government authorities to function effectively.

These defects in the 1999 constitution of Federal Republic of Nigeria bring to bear some salient questions surrounding the ambiguities and contradictions inherent in the wordings the constitution:

Why is the constitution deliberately nebulous on the question of local Government autonomy?

\section{References}

1. Wheare KC (1963) Federal Government (4thedn), London: Oxford University Press.

2. Ranny A (1976) Governing: An introduction to Political Science (8thedn).

3. Acheoah AO (2018) Local Government: the Underutilized governance structure in Nigeria, a Paper, Department of Political science University of Lagos, Akoka, Nigeria.

4. Acheoah AO (2018) The Crisis of Multi-ethnic Federations: A Case of Nigeria, a Paper, Department of Political science, akoka, Lagos, Nigeria

5. Joseph R (1991) Democracy and Prebendal Politics in Nigeria: the Rise and Fall of the Second Republic. Ibadan, Spectrum Books. 